\title{
Hydrochemical Characteristics of Groundwater and Dominant Water-Rock Interactions in the Delingha Area, Qaidam Basin, Northwest China
}

\author{
Biao Zhang ${ }^{1,2,3}$, Dan Zhao ${ }^{1,2,4} \mathbb{D}^{\mathrm{D}}$, Pengpeng Zhou ${ }^{1,2, *}$, Shen $\mathrm{Qu}{ }^{1,2}$, Fu Liao ${ }^{1,2}$ and \\ Guangcai Wang 1,2,*(D)
}

1 State Key Laboratory of Biogeology and Environmental Geology \& MOE Key Laboratory of Groundwater Circulation and Environment Evolution, China University of Geosciences, Beijing 100083, China; zhangb0517@karst.ac.cn (B.Z.); zhaodan2209@163.com (D.Z.); qushen19930729@163.com (S.Q.); cugbliaofu@163.com (F.L.)

2 School of Water Resources \& Environment, China University of Geosciences, Beijing 100083, China

3 Institute of Karst Geology, Chinese Academy of Geological Sciences, Guilin 541004, China

4 China Aero Geophysical Survey and Remote Sensing Center for Natural Resources, Beijing 100083, China

* Correspondence: zhoupeng@cugb.edu.cn (P.Z.); wanggc@pku.edu.cn (G.W.)

Received: 19 February 2020; Accepted: 13 March 2020; Published: 16 March 2020

\begin{abstract}
Groundwater is undoubtedly important for water supplies and eco-environment protection, especially for arid and semi-arid regions. Analyzing the characteristics and evolution of groundwater is significant for the rational management of groundwater resources. This study investigated the hydrogeochemical characteristics and evolutions of groundwater in the Delingha area, northeast of the Qaidam Basin, northwest China, with a total of 123 water samples, including 105 unconfined groundwater samples, 12 confined groundwater samples, and 6 surface water samples. Hydrochemical results showed that the unconfined and confined groundwater presented diversity in ion concentration. Total Dissolved Solids (TDS) of the unconfined groundwater increased from 146.5 to $8954 \mathrm{mg} / \mathrm{L}$ along the groundwater flow direction. The groundwater hydrochemical types were $\mathrm{HCO}_{3}-\mathrm{Ca} \cdot \mathrm{Mg}$ and $\mathrm{HCO}_{3} \cdot \mathrm{SO}_{4}-\mathrm{Ca} \cdot \mathrm{Mg}$ in the mountain front area, $\mathrm{SO}_{4} \cdot \mathrm{HCO}_{3}-\mathrm{Ca} \cdot \mathrm{Mg}$ and $\mathrm{SO}_{4} \cdot \mathrm{Cl}-\mathrm{Ca} \cdot \mathrm{Mg}$ types in the alluvial-lacustrine plain, and $\mathrm{Cl} \cdot \mathrm{SO}_{4}-\mathrm{Na}$ and $\mathrm{Cl}-\mathrm{Na}$ types in the lacustrine plain. The saturation index showed that parts of the groundwater samples were supersaturated with carbonate minerals (calcite and dolomite); however, all the samples were undersaturated with evaporite minerals (halite and gypsum). Groundwater chemical evolution is mainly controlled by evaporite and carbonate mineral dissolutions, aluminosilicates weathering, and cation exchange.
\end{abstract}

Keywords: hydrochemistry evolution; groundwater; water-rock interactions; Delingha

\section{Introduction}

Water shortage has been a critical issue in many parts of the world, especially in arid and semi-arid areas [1-4]. Qaidam Basin, which is located in Northwest China, is a typical arid area [5]. Because of the lack of surface-water and precipitation, groundwater has been the main water resource in this area. Sustainable management of groundwater has become a critical issue for this area. Understanding the hydrochemical characteristics of the local groundwater could provide guidance for sustainable groundwater development [6].

The hydrochemistry of groundwater is generally regulated by precipitation, geological structure, rock type, residence time, and geochemical processes along the groundwater flow paths $[7,8]$. Recent studies for the groundwater of Qaidam area have focused on the recharge source, circulation, hydrochemical characteristics, and hydrochemical evolution of the local groundwater [4,5]. For 
example, a previous study discussed the hydrochemical characteristics, hydrochemical evolution, and recharge sources of groundwater in Nomhon area and Golmud area of the southern Qaidam Basin. This study concluded that the main recharge source of groundwater was the atmospheric precipitation and that ionic components were mainly derived from water-rock interactions [5]. And an isotopic study of the Glomud River and Nalingguole River illustrated the interaction relationship between surface-water and groundwater in an alluvial-proluvial fan and the groundwater recharge source from meteoric waters and mountain snowmelt [9]. Although those previous studies revealed the groundwater hydrochemistry mechanism in this arid area, there is no systematic research for discussing the pattern of groundwater mineral sources and hydrochemical evolution on a regional scale from the mountain recharge area to the lacustrine plain discharge region in Delingha.

This research mainly presents a hydrochemical investigation of groundwater in Delingha to determine the hydrochemical characteristics, mineral sources, and hydrochemical evolution along the groundwater flow path. The specific aims are as follows: (1) assessing the groundwater hydrochemical characteristics and groundwater quality, (2) revealing the dominating hydrochemical processes and mineral sources of the groundwater. The results of this study will be beneficial for understanding the groundwater hydrochemical evolution on a basin scale and for supporting the elaborate management of groundwater resources.

\section{Materials and Methods}

\subsection{Regional Hydrogeology}

This study area, bounded by the Zongwulong Mountain in the north, Delingha hills in the south, Buhete Mountain in the east, and Delingha uplift in the west, is located in the northeastern of the Qaidam Basin, northwest China (Figure 1). This area extends between longitudes of $96^{\circ} 56^{\prime}-97^{\circ} 32^{\prime}$ $\mathrm{E}$ and latitudes of $37^{\circ} 08^{\prime}-37^{\circ} 24^{\prime} \mathrm{N}$, encompassing an area of $1200 \mathrm{~km}^{2}$. The highest elevation (5030 $\mathrm{m}$ ) is in the Zongwulong Mountain, and the lowest $(2820 \mathrm{~m})$ is in Toson lake (Figure 1). The relative elevation difference is $2210 \mathrm{~m}$.

The geomorphological units in this area can be mainly divided into four types: middle-high mountain areas, low mountains and hilly areas, Gobi Desert, and alluvial-lacustrine plain. The climate is featured as a typical arid continental climate. The average annual temperature is $3.9^{\circ} \mathrm{C}$, average annual rainfall is $169.3 \mathrm{~mm}$ within the rainy season from June to October. And the average annual potential evaporation is $2036 \mathrm{~mm}$, which is more than ten times the average annual rainfall.

The geologic outcrops in this study area include sediments of Sinian, Carboniferous, Permian, and Trias up to Quaternary periods. The outcrops of bedrock are mainly distributed in the mountain area. The alluvial fan and lacustrine plain were comprised of the Quaternary deposits of coarse sand, fine sand and sandy clay, with the thickness ranging from 0 to $500 \mathrm{~m}$ (Figure 2). Bedrock fissure groundwater occurring in sandstone and slates of the Triassic and Permian periods is widely distributed in the north and east of this study area. The carbonate fissure karst water occurring in phyllite and limestone of the Carboniferous period is mainly distributed in the south slope of Zongwulong Mountain and mainly receives the replenishment from atmospheric precipitation and snowmelt. Clastic rock fracture groundwater mainly occurs in the hilly area and alluvial-lacustrine plain, in where the lithology is composed of glutenite, sandstone, and mudstone interbeds. Loose sediment groundwater is the main water resource of this region, with a water table depth of 4-60 m.

The main rivers in the Delingha area are the Baying river and Baishui river (Figure 1). The Baying river is the largest river in this area, originating from the Zongwulong Mountain and running through the entire Delingha city. After passing through the Delingha city, it leaks heavily into the aquifer and supplies the groundwater. Then, part of groundwater flows eastward and eventually flows into the Gahai Lake; and most of the groundwater flows westward and finally flows into the Hurleg Lake. Along the flowing path to Hurleg Lake, part of groundwater overflows to the surface in the way of spring (Figure 2). 


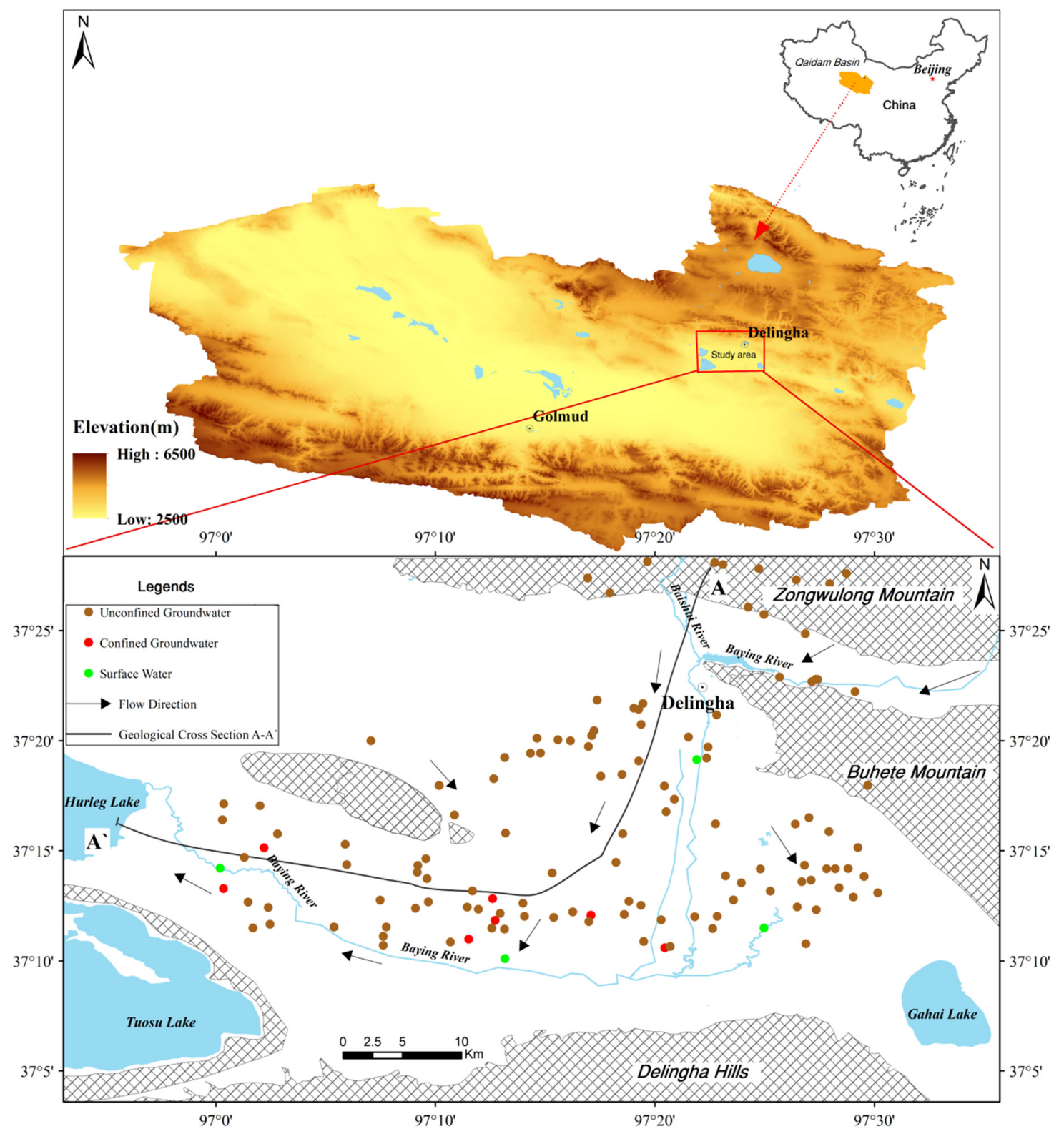

Figure 1. Schematic map of the study area and sampling sites.

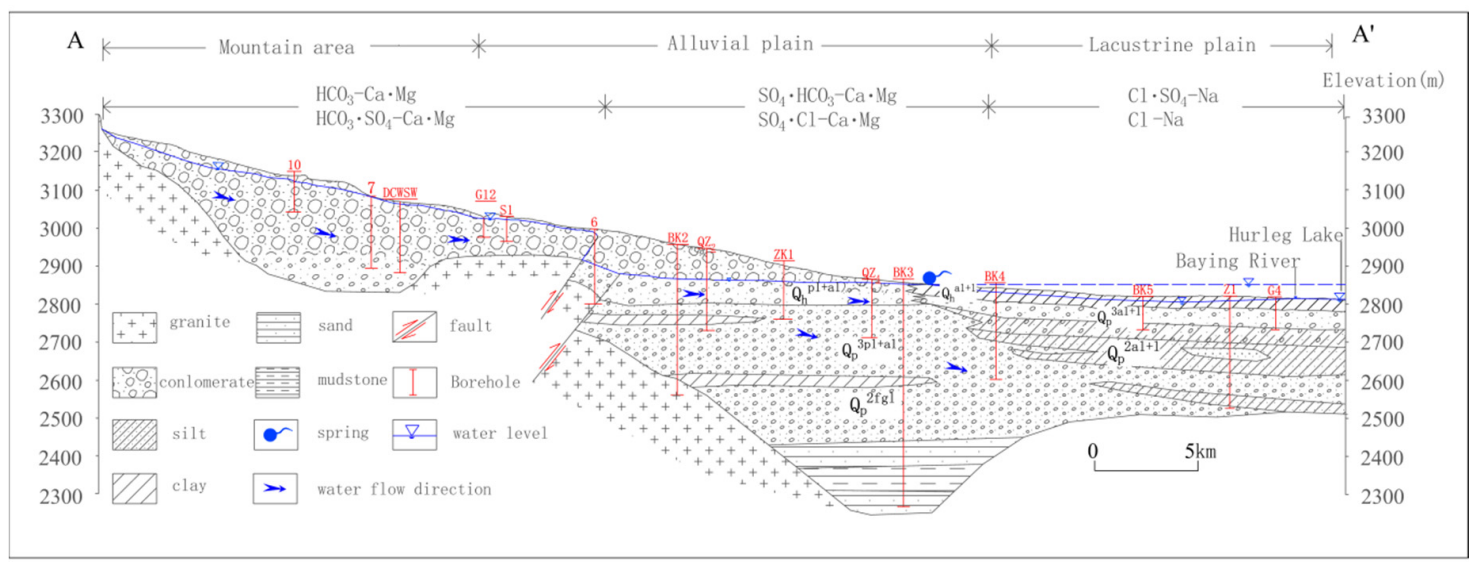

Figure 2. Hydrogeological profile of $\mathrm{A}-\mathrm{A}^{\prime}$. 


\subsection{Sampling and Analysis Methods}

A total of 123 water samples were collected from May to October 2016 in the Delingha region. Those samples (including 6 surface-water, 105 unconfined groundwater and 12 confined groundwater samples) were collected along the general groundwater flow direction, from Zongwulong Mountain to Hurleg Lake (Figure 1). Samples of surface-water were collected from the Baying river, and samples of groundwater were collected from wells, boreholes and springs. The depths of those wells and boreholes of the unconfined aquifer are about $30-150 \mathrm{~m}$. And the depths of boreholes of the confined aquifer, which is in the southern lacustrine plain, range from 100 to $500 \mathrm{~m}$.

All the water samples were stored in portable bottles and then analyzed in the Laboratory of Groundwater Sciences and Engineering of the Institute of Hydrogeology and Environmental Geology, Chinese Academy of Geological Sciences. Major cations $\left(\mathrm{K}^{+}, \mathrm{Na}^{+}, \mathrm{Ca}^{2+}, \mathrm{Mg}^{2+}\right)$ were measured with ICP-OES, anions $\left(\mathrm{Cl}^{-}, \mathrm{SO}_{4}{ }^{2-}\right)$ were carried out by spectrophotometry (DX-120IC), and $\mathrm{HCO}_{3}{ }^{-}$and TDS were measured by acid-base titration and gravimetric processes, respectively. According to the charge balance verification of all hydrochemical data, the ionic balance error was within the limit value of $\pm 5 \%$, indicating the accuracy of our data.

\section{Results and Discussion}

\subsection{Hydrochemical Characteristics}

Statistics analysis of the hydrochemical parameters of 123 water samples is shown in Table 1, containing the minimum, maximum, and mean values of the major ions and hydrochemical parameters. As shown in Table 1, the concentration of cations in all water samples follows the same order of $\mathrm{Na}^{+}>$ $\mathrm{Ca}^{2+}>\mathrm{Mg}^{2+}>\mathrm{K}^{+}$. However, the order of the concentration of anions in unconfined groundwater $\left(\mathrm{SO}_{4}{ }^{2-}>\mathrm{Cl}^{-}>\mathrm{HCO}_{3}{ }^{-}\right)$is different with that of the confined groundwater and surface water $\left(\mathrm{HCO}_{3}{ }^{-}\right.$ $>\mathrm{SO}_{4}{ }^{2-}>\mathrm{Cl}^{-}$). This implies the different water types that will be discussed in Section 3.2 and can indicate the difference of some geochemical processes (such as evaporation or water-rock interactions) occurring in different water.

Table 1. Summary of descriptive statistics of different hydrochemical parameters of all the 123 samples (including 6 surface water samples, 12 confined groundwater samples, and 105 unconfined groundwater samples).

\begin{tabular}{cccccccccc}
\hline \multirow{2}{*}{$\begin{array}{c}\text { Hydrochemical } \\
\text { Components }\end{array}$} & \multicolumn{2}{c}{ Unconfined Groundwater } & \multicolumn{2}{c}{ Confined Groundwater } & \multicolumn{3}{c}{ Surface Water } \\
\cline { 2 - 10 } & Min & Max & Average & Min & Max & Average & Min & Max & Average \\
\hline $\mathrm{K}^{+}(\mathrm{mg} / \mathrm{L})$ & 0.5 & 49.5 & 6.9 & 2.6 & 5.0 & 3.6 & 1.2 & 6.6 & 3.7 \\
$\mathrm{Na}^{+}(\mathrm{mg} / \mathrm{L})$ & 10.8 & 1885.0 & 227.4 & 41.9 & 150.0 & 82.0 & 8.9 & 262.0 & 87.9 \\
$\mathrm{Ca}^{2+}(\mathrm{mg} / \mathrm{L})$ & 26.1 & 696.0 & 112.6 & 25.2 & 74.4 & 54.1 & 6.7 & 91.4 & 64.4 \\
$\mathrm{Mg}^{2+}(\mathrm{mg} / \mathrm{L})$ & 6.1 & 410.0 & 53.5 & 12.4 & 42.0 & 23.0 & 1.4 & 78.4 & 26.2 \\
$\mathrm{Cl}^{-}(\mathrm{mg} / \mathrm{L})$ & 14.2 & 1887.0 & 279.1 & 47.8 & 111.0 & 67.1 & 3.5 & 325.0 & 113.8 \\
$\mathrm{SO}_{4}{ }^{2-}(\mathrm{mg} / \mathrm{L})$ & 12.5 & 4091.0 & 346.5 & 43.5 & 221.0 & 106.8 & 21.4 & 303.0 & 126.2 \\
$\mathrm{HCO}_{3}^{-}(\mathrm{mg} / \mathrm{L})$ & 97.6 & 579.0 & 267.8 & 170.0 & 335.0 & 237.2 & 17.9 & 391.0 & 198.7 \\
$\left.\mathrm{TDS}^{-m g} / \mathrm{L}\right)$ & 146.5 & 8954.0 & 1142.0 & 314.0 & 662.0 & 443.1 & 52.0 & 1246.0 & 514.0 \\
$\mathrm{pH}$ & 7.00 & 8.00 & 7.97 & 8.00 & 9.00 & 8.08 & 8.00 & 8.00 & 8.00 \\
\hline
\end{tabular}

TDS, which is a comprehensive hydrochemical parameter, can be used to reflect the groundwater quality [10]. As shown in Table 1, TDS values of the unconfined groundwater range from 52 to $8954 \mathrm{mg} / \mathrm{L}$ with a mean value of $1043 \mathrm{mg} / \mathrm{L}$. And it can be concluded that a gradually increasing trend of the TDS value of unconfined groundwater along the flow direction is occurring. This is mainly due to the fact that the unconfined groundwater in the recharge area (northern mountains area) is directly recharged from precipitation and snowmelt, while the groundwater in the discharge area (southeast and southwest area) may be influenced by relatively strong evaporation or water-rock reactions, especially in Gahai Lake and Hurleg Lake. However, the confined groundwater is always fresh water with TDS $<1 \mathrm{~g} / \mathrm{L}$. This hydrochemistry difference between unconfined groundwater and 
confined groundwater indicates the difference of some hydrochemical processes (such as evaporation) occurring in those two aquifers. In addition, the surface-water's hydrochemistry feature (concentration less than that of unconfined groundwater, but greater than that of the confined groundwater) implies the great recharge and runoff conditions and slight evaporation effects in the downstream area of Baying river. These hydrochemistry distributions in different areas and different aquifers can guide the selection for water resource field.

The $\mathrm{pH}$ values vary from 7 to 9 with a mean value of 8 , indicating weak alkaline conditions. According to the National Drinking Water Standard of China, the standard pH value of residents' drinking water is 6.5-8.5. Thus, the analysis result of $\mathrm{pH}$ indicates that most water in this area is within the potable range.

The spatial distribution of $\mathrm{Na}^{+}, \mathrm{Ca}^{2+}, \mathrm{Mg}^{2+}, \mathrm{K}^{+}$cations shows an increasing tendency along the groundwater flow direction (from the mountain area to the alluvial-lacustrine plain). $\mathrm{Na}^{+}$is the dominant cation in this area, with concentration from $3.5 \mathrm{mg} / \mathrm{L}$ to $1887 \mathrm{mg} / \mathrm{L}$ in water samples; $\mathrm{Ca}^{2+}$, $\mathrm{Mg}^{2+}$ are the secondary cations in water samples; concentration of $\mathrm{K}^{+}$is the lowest, with a mean value of $6.9 \mathrm{mg} / \mathrm{L}$.

The concentration of $\mathrm{Cl}^{-}$also shows a gradual increase from the mountain area to the alluvial-lacustrine plain. The mean concentration of $\mathrm{Cl}^{-}$is $279.1,67.1$, and $113.8 \mathrm{mg} / \mathrm{L}$ for unconfined groundwater, confined groundwater, and surface-water, respectively. All the unconfined groundwater samples and parts of confined groundwater samples have $\mathrm{Cl}^{-}$values beyond the drinking water limit of $250 \mathrm{mg} / \mathrm{L}$.

The mean concentration value of $\mathrm{HCO}_{3}{ }^{-}$is $267.8,237.2$, and $198.7 \mathrm{mg} / \mathrm{L}$ for unconfined groundwater, confined groundwater, and surface-water, respectively. The concentration of $\mathrm{HCO}_{3}{ }^{-}$ displays an increasing pattern from the mountain region to the alluvial-lacustrine area. And the $\mathrm{HCO}_{3}{ }^{-}$is the most dominant anion of water in the mountain area. And the average concentration of $\mathrm{SO}_{4}{ }^{2-}$ is $346.6,106.8$, and $126.2 \mathrm{mg} / \mathrm{L}$ from unconfined groundwater, confined groundwater, and surface-water, respectively. $\mathrm{SO}_{4}{ }^{2-}$ is the dominant anion of water in the alluvial plain.

The results of the main hydrochemical parameter correlation are presented in Table 2. The strong positive correlations between TDS and mainly ions $\left(\mathrm{Na}^{+}, \mathrm{Cl}^{-}, \mathrm{Mg}^{2+}, \mathrm{SO}_{4}{ }^{2-}, \mathrm{Ca}^{2+}, \mathrm{K}^{+}\right.$, and $\left.\mathrm{HCO}_{3}{ }^{-}\right)$ suggest the important role played by those mentioned ions in the groundwater hydrochemistry. There are good corrections between $\mathrm{Na}^{+}$and $\mathrm{Cl}^{-}(0.974), \mathrm{Ca}^{2+}$ and $\mathrm{SO}_{4}{ }^{2-}(0.915), \mathrm{Ca}^{2+} \mathrm{and}^{2} \mathrm{Mg}^{2+}$ (0.858), indicating that the major ions of groundwater may originate from the halite, gypsum, and carbonate dissolution.

Table 2. Correlation matrix for all water samples $(n=123)$.

\begin{tabular}{ccccccccc}
\hline Ion & $\mathbf{K}^{+}$ & $\mathbf{N a}^{+}$ & $\mathbf{C a}^{2+}$ & $\mathbf{M g}^{2+}$ & $\mathbf{C l}^{-}$ & $\mathbf{S O}_{4}^{2-}$ & $\mathbf{H C O}_{3}^{-}$ & TDS \\
\hline $\mathrm{K}^{+}$ & 1.000 & & & & & & & \\
$\mathrm{Na}^{+}$ & 0.755 & 1.000 & & & & & & \\
$\mathrm{Ca}^{2+}$ & 0.591 & 0.540 & 1.000 & & & & & \\
$\mathrm{Mg}^{2+}$ & 0.595 & 0.629 & 0.858 & 1.000 & & & & \\
$\mathrm{Cl}^{-}$ & 0.777 & 0.974 & 0.491 & 0.585 & 1.000 & & & \\
$\mathrm{SO}_{4}^{2-}$ & 0.512 & 0.562 & 0.915 & 0.890 & 0.443 & 1.000 & & \\
$\mathrm{HCO}_{3}^{-}$ & 0.380 & 0.421 & 0.540 & 0.606 & 0.374 & 0.492 & 1.000 & \\
$\mathrm{TDS}^{2}$ & 0.775 & 0.937 & 0.786 & 0.841 & 0.893 & 0.798 & 0.532 & 1.000 \\
\hline
\end{tabular}

\subsection{Groundwater Hydrochemical Types}

The piper diagram is an important means to comprehend the hydrochemical characteristics, hydrochemical types and hydrochemical evolution in groundwater [11,12]. Figure 3 shows that the surface water and confined groundwater are characterized by $\mathrm{HCO}_{3}-\mathrm{Ca} \cdot \mathrm{Na}$ and $\mathrm{HCO}_{3} \cdot \mathrm{SO}_{4}-\mathrm{Ca} \cdot \mathrm{Na}$ types. However, the type of water chemistry for unconfined groundwater is relatively complex in this study area, including $\mathrm{HCO}_{3}-\mathrm{Ca} \cdot \mathrm{Mg}, \mathrm{HCO}_{3} \cdot \mathrm{SO}_{4}-\mathrm{Ca} \cdot \mathrm{Mg}, \mathrm{SO}_{4} \cdot \mathrm{HCO}_{3}-\mathrm{Ca} \cdot \mathrm{Mg}, \mathrm{SO}_{4} \cdot \mathrm{Cl}-\mathrm{Ca} \cdot \mathrm{Mg}, \mathrm{Cl} \cdot \mathrm{SO}_{4}-\mathrm{Na}$, and $\mathrm{Cl}-\mathrm{Na}$ types. The hydrochemical types of the unconfined groundwater in the mountain area 
(recharge area) were mainly $\mathrm{HCO}_{3}-\mathrm{Ca} \cdot \mathrm{Mg}$ and $\mathrm{HCO}_{3} \cdot \mathrm{SO}_{4}-\mathrm{Ca} \cdot \mathrm{Mg}$ types, those in the alluvial-lacustrine plain (runoff area) were mainly $\mathrm{SO}_{4} \cdot \mathrm{HCO}_{3}-\mathrm{Ca} \cdot \mathrm{Mg}, \mathrm{SO}_{4} \cdot \mathrm{Cl}-\mathrm{Ca} \cdot \mathrm{Mg}$ types, and those in the lacustrine plain (discharge area) were mainly $\mathrm{Cl} \cdot \mathrm{SO}_{4}-\mathrm{Na}$ and $\mathrm{Cl}-\mathrm{Na}$ types (Figure 2).

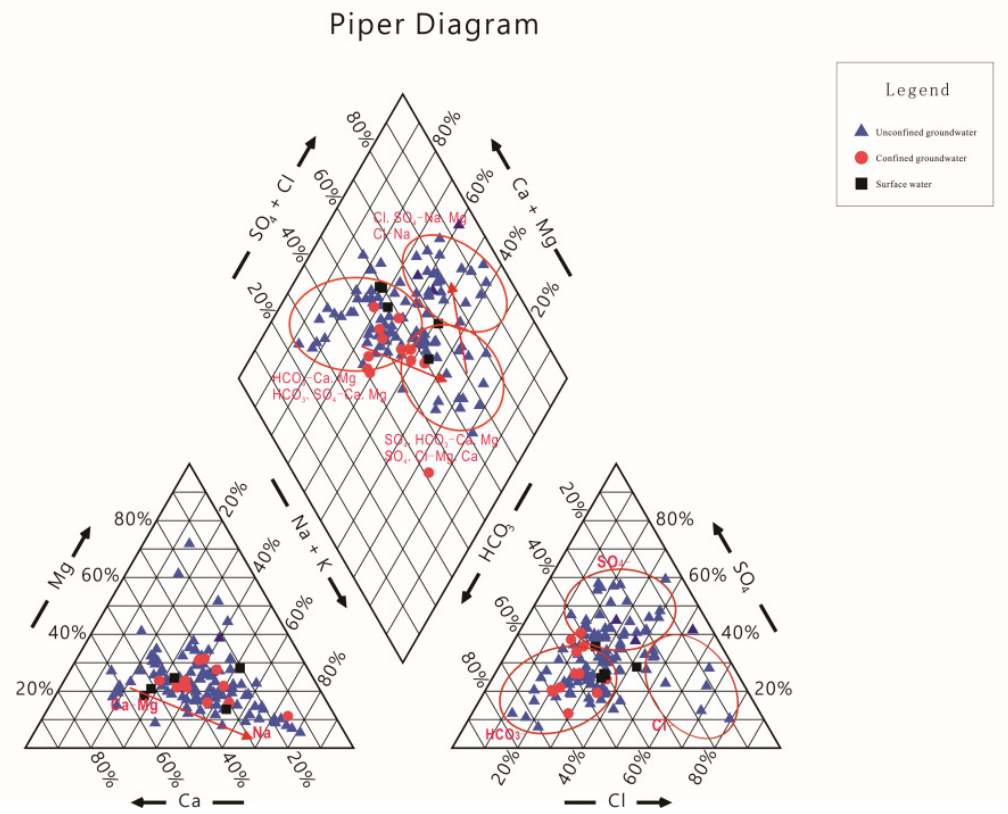

Figure 3. Piper diagram of all groundwater and surface water samples.

According to the analysis of groundwater types in the Delingha area, there is a clear zoning distribution along the flow path (Figure 4). The groundwater recharge area (mountainous area) is mainly featured with $\mathrm{HCO}_{3}$-type, the runoff area (the alluvial-lacustrine plain) is mainly represented by $\mathrm{SO}_{4}$-type, and the groundwater discharge area (near the Gahai Lake and Keluke Lake) is mainly featured with Cl-type.

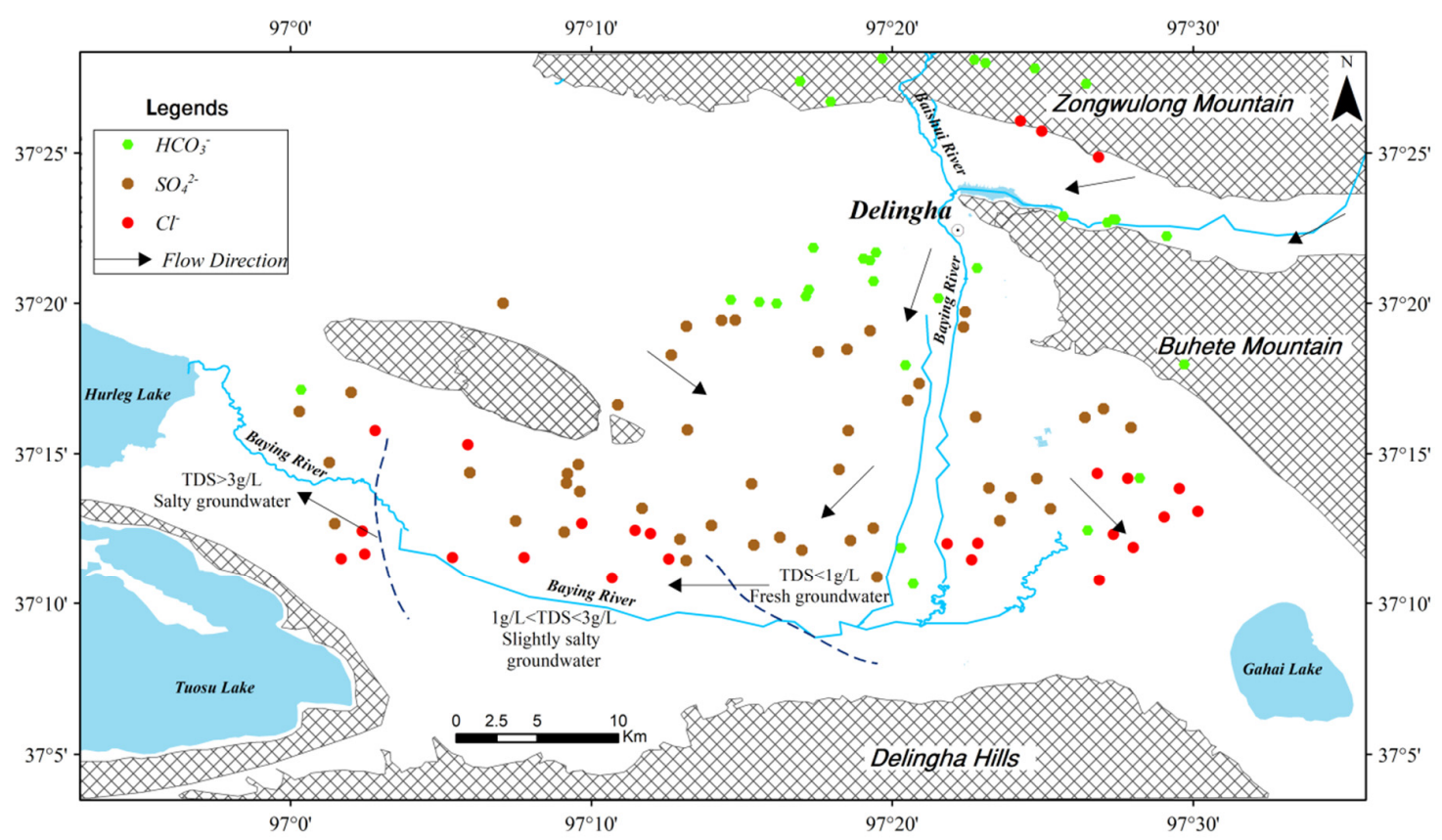

Figure 4. The distribution map of water types and Total Dissolved Solids (TDS) in the Delingha area. 


\subsection{Main Hydrochemical Processes}

Gibbs diagrams were constructed by the equivalence ratios of $\mathrm{Na}^{+} /\left(\mathrm{Na}^{+}+\mathrm{Ca}^{2+}\right)$ and $\mathrm{Cl}^{-} /\left(\mathrm{Cl}^{-}\right.$ $+\mathrm{HCO}_{3}{ }^{-}$) versus TDS. This method has been widely used to identify hydrogeochemical evolution, which involves precipitation, rock weathering, and evaporation-crystallization processes [13]. In the Gibbs diagram, the water samples are located in the lower right, with low TDS values but high values of $\mathrm{Na}^{+} /\left(\mathrm{Na}^{+}+\mathrm{Ca}^{2+}\right)$ or $\mathrm{Cl}^{-} /\left(\mathrm{Cl}^{-}+\mathrm{HCO}_{3}{ }^{-}\right)$, indicating that the chemical compositions have been influenced by atmospheric precipitation; samples fall in the center region, suggesting that the rock weathering process is dominant; and samples with high TDS values and high $\mathrm{Na}^{+} /\left(\mathrm{Na}^{+}+\mathrm{Ca}^{2+}\right)$ and $\mathrm{Cl}^{-} /\left(\mathrm{Cl}^{-}+\mathrm{HCO}_{3}{ }^{-}\right)$values fall in the upper right region, indicating the influence of evaporation.

As shown in Figure 5, all the confined groundwater and surface-water samples and most of the unconfined groundwater samples lie in the rock-weathering process dominance area, indicating that the main hydrochemical process of the local water is water-rock interaction. However, a few of unconfined groundwater samples collected from the lacustrine plain with a water table depth of 3-5 m are located in the transition region between evaporation and rock-weathering, suggesting that the water in the lacustrine plain was influenced both by evaporation and water-rock interaction.
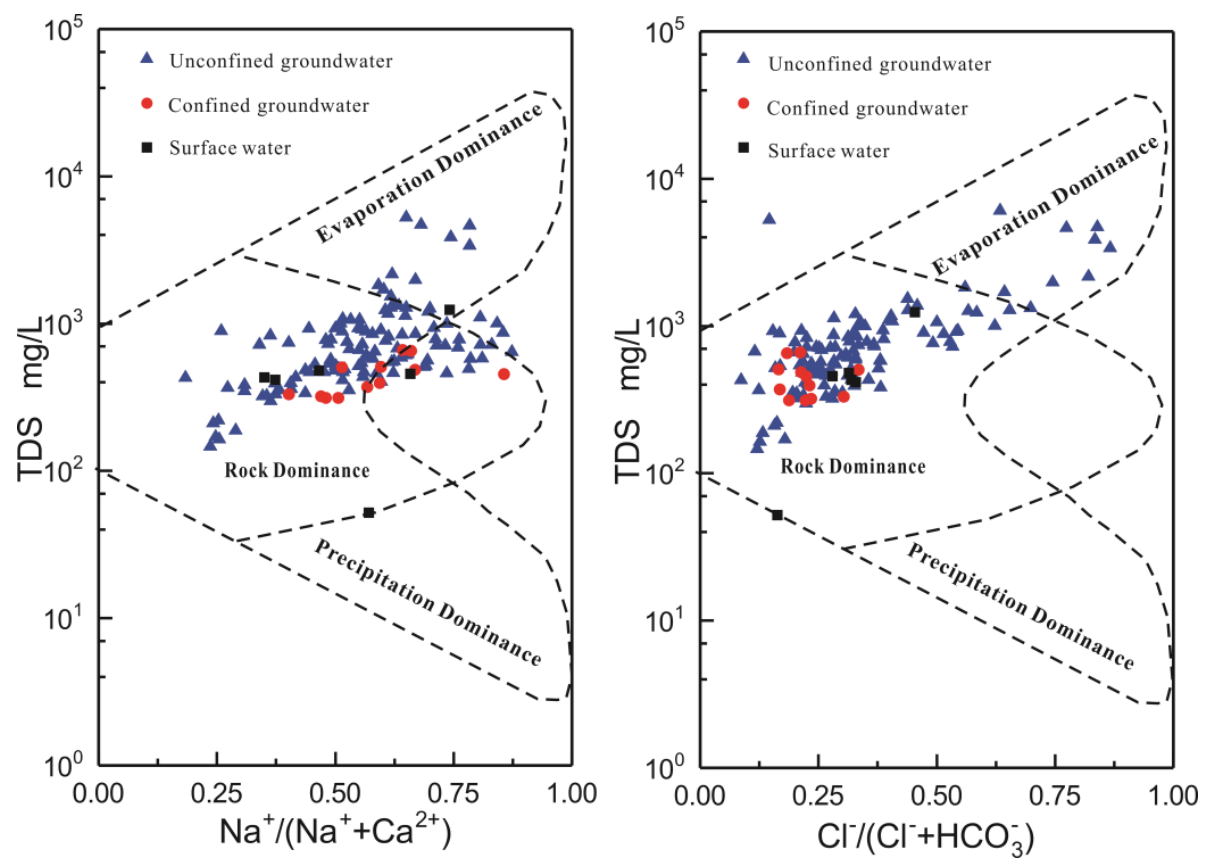

Figure 5. Gibbs diagrams for the major-ion composition of the groundwater in the Delingha area.

\subsection{Major Ion Relations in the Groundwater}

The major ion relationship was plotted to explain the hydrochemical evolution processes and the controlling mechanism of the local groundwater. The ion ratio relationship can further assist in comprehending the process of water-rock interactions in this area. Thus, according to the hydrochemistry data, ratio graphs of the major ion relationship were plotted (Figure 6).

If the molar ratio of $\mathrm{Na}^{+} / \mathrm{Cl}^{-}$is approximate to 1, indicating that halite dissolution mainly contributes to $\mathrm{Na}^{+}$concentration in groundwater; if this ratio is greater than 1 , meaning that there is silicate weathering or a cation exchange; and if this ratio is less than 1, representing an anthropogenic disturbance. As shown, Figure 6a presents the ion relationship between $\mathrm{Na}^{+}$and $\mathrm{Cl}^{-}$. A few of the groundwater samples were along the 1:1 trend line, and the other samples lay above the 1:1 trend line, suggesting that halite dissolution, silicate weathering, and cation exchange are important sources of $\mathrm{Na}^{+}$. In addition, the saturation index (SI) of halite in Section 3.5 can further prove this view of 
the sources of $\mathrm{Na}^{+}$and $\mathrm{Cl}^{-}$. And few groundwater sample lie under the 1:1 trend line (Figure 6a), indicating that anthropogenic disturbance is weak in this area.
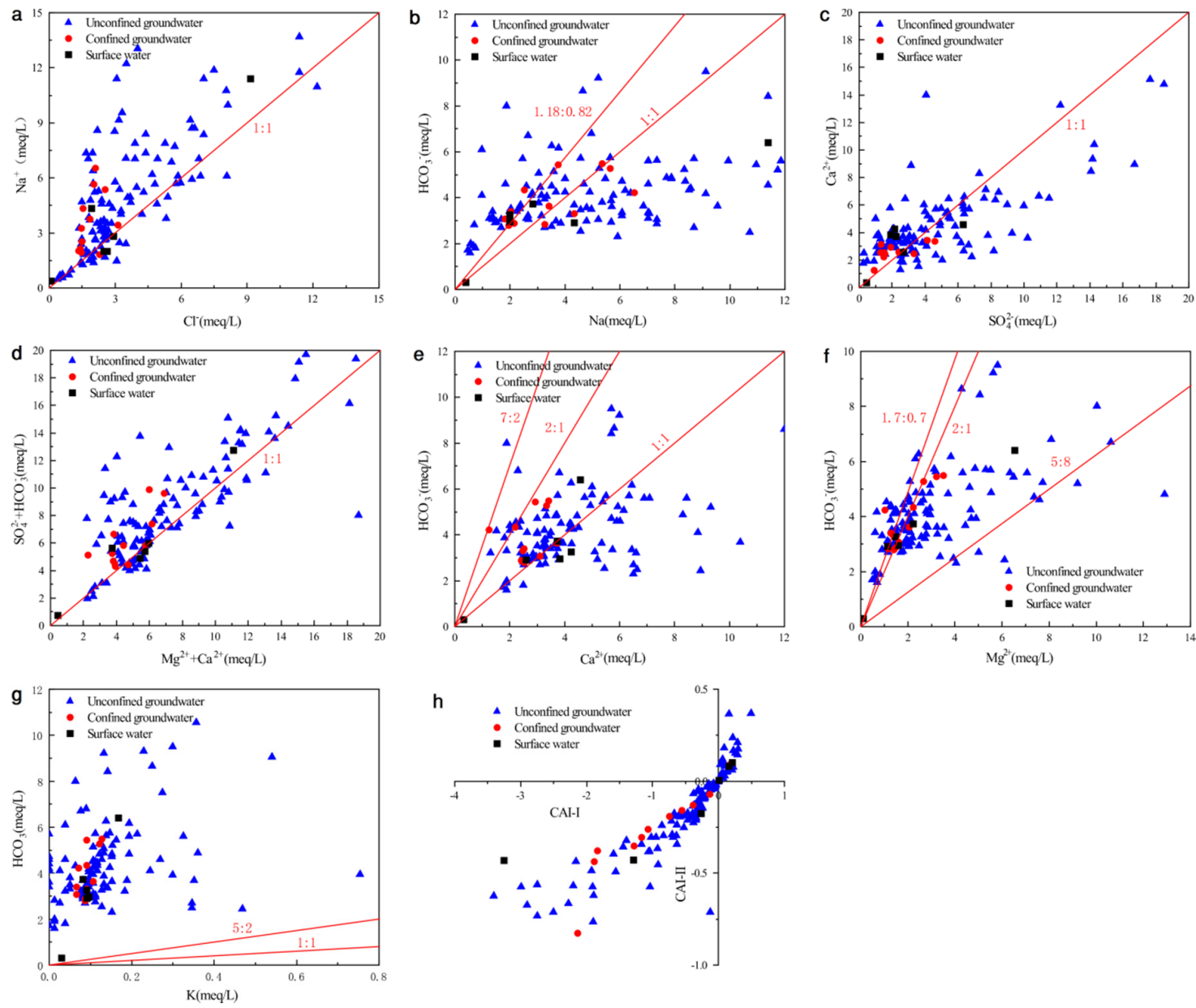

Figure 6. Scatter plots showing the correlation of major cations/anions to discriminate the geochemical processes. (a) $\mathrm{Na}^{+}$vs. $\mathrm{Cl}^{-}$, (b) $\mathrm{Na}^{+}$vs. $\mathrm{HCO}_{3}{ }^{-}$, (c) $\mathrm{Ca}^{2+}$ vs. $\mathrm{SO}_{4}{ }^{2-}$, (d) $\left(\mathrm{SO}_{4}{ }^{2-}+\mathrm{HCO}_{3}{ }^{-}\right)$vs. $\left(\mathrm{Ca}^{2+}+\mathrm{Mg}^{2+}\right),\left(\right.$ e) $\mathrm{Ca}^{2+}$ vs. $\mathrm{HCO}_{3}^{-}$, (f) $\mathrm{Mg}^{2+}$ vs. $\mathrm{HCO}_{3}^{-},(\mathrm{g}) \mathrm{HCO}_{3}^{-}$vs. $\mathrm{K}^{+}$, (h) scatter plot of Schoeller indices.

If the $\mathrm{HCO}_{3}{ }^{-} / \mathrm{Na}^{+}$ratio of water samples is $1: 1$ and $0.82: 1.18$, indicating that weathering of silicate minerals (albite and plagioclase) occurs in the groundwater. The corresponding hydrochemical reactions can be seen in Table 3 (reactions of 3 and 4). As shown in Figure 6b, only a few water samples were plotted between the 1:1 line and line 0.82:1.18. Furthermore, the correlation coefficient between $\mathrm{Na}^{+}$and $\mathrm{HCO}_{3}{ }^{-}$is low (Table 2). These data suggest that the dissolution of albite and plagioclase is not the main source of $\mathrm{Na}^{+}$and $\mathrm{HCO}_{3}{ }^{-}$in groundwater. Meanwhile, a ratio of $\mathrm{Na}^{+} / \mathrm{HCO}_{3}{ }^{-}$larger than 1 showed the excess of $\mathrm{Na}^{+}$, which is mainly because of the dissolution of halite and cation exchange. 
Table 3. Weathering of minerals reactions and ions ratio in the groundwater.

\begin{tabular}{|c|c|c|}
\hline & Reactions & Ratio \\
\hline a 1 & $\mathrm{NaCl}($ Halite $)=\mathrm{Na}^{+}+\mathrm{Cl}^{-}$ & $\mathrm{Na}: \mathrm{Cl}=1: 1$ \\
\hline a 2 & $\mathrm{CaSO}_{4}($ Gypsum $)=\mathrm{Ca}^{2+}+\mathrm{SO}_{4}^{-}$ & $\mathrm{Ca}: \mathrm{SO}_{4}=1: 1$ \\
\hline c 3 & $\begin{array}{c}2 \mathrm{NaAlSi}_{3} \mathrm{O}_{8}(\text { Albite })+9 \mathrm{H}_{2} \mathrm{O}+2 \mathrm{H}_{2} \mathrm{CO}_{3}=\mathrm{Al}_{2} \mathrm{Si}_{2} \mathrm{O}_{5}(\mathrm{OH})_{4}+ \\
2 \mathrm{Na}^{+}+2 \mathrm{HCO}_{3}^{-}+4 \mathrm{H}_{4} \mathrm{SiO}_{4}\end{array}$ & $\mathrm{Na}: \mathrm{HCO}_{3}{ }^{-}=1: 1$ \\
\hline c 4 & $\begin{array}{c}\left(\mathrm{Na}_{0.82} \mathrm{Ca}_{0.18}\right) \mathrm{Al}_{1.18} \mathrm{Si}_{2.82} \mathrm{O}_{8}(\text { Plagioclase })+1.18 \mathrm{CO}_{2}+ \\
1.77 \mathrm{H}_{2} \mathrm{O}=0.82 \mathrm{Na}^{+}+0.18 \mathrm{Ca}^{2+}+1.18 \mathrm{HCO}_{3}^{-}+ \\
0.59 \mathrm{Al}_{2} \mathrm{Si}_{2} \mathrm{O}_{5}(\mathrm{OH})_{4}+1.64 \mathrm{SiO}_{2}\end{array}$ & $\begin{array}{c}\mathrm{Na}: \mathrm{HCO}_{3}{ }^{-}=0.82: 1.18 \\
\mathrm{Ca}: \mathrm{HCO}_{3}=0.18: 0.59\end{array}$ \\
\hline b 5 & $\begin{array}{c}2 \mathrm{CaAl}_{2} \mathrm{Si}_{2} \mathrm{O}_{8}(\text { Anorthite })+4 \mathrm{CO}_{2}+6 \mathrm{H}_{2} \mathrm{O}= \\
2 \mathrm{Al}_{2} \mathrm{Si}_{2} \mathrm{O}_{5}(\mathrm{OH})_{4}+\mathrm{Ca}^{2+}+4 \mathrm{HCO}_{3}^{-}\end{array}$ & $\mathrm{Ca}: \mathrm{HCO}_{3}=1: 2$ \\
\hline${ }^{\mathrm{c}} 6$ & $\begin{array}{c}\mathrm{CaMg}_{0.7} \mathrm{Fe}_{0.3} \mathrm{Si}_{2} \mathrm{O}_{6}(\text { Pyroxene })+3.4 \mathrm{CO}_{2}+2.3 \mathrm{H}_{2} \mathrm{O}=\mathrm{Ca}^{2+}+ \\
0.7 \mathrm{Mg}^{2+}+2 \mathrm{SiO}_{2}+3.4 \mathrm{HCO}_{3}{ }^{-}+0.3 \mathrm{H}^{+}+0.3 \mathrm{Fe}(\mathrm{OH})_{3}\end{array}$ & $\begin{array}{c}\mathrm{Ca}: \mathrm{HCO}_{3}=1: 1.7 \\
\mathrm{Mg}: \mathrm{HCO}_{3}=0.7: 1.7\end{array}$ \\
\hline b 7 & $\begin{array}{c}\mathrm{Ca}_{2} \mathrm{Mg}_{5} \mathrm{Si}_{8} \mathrm{O}_{22}(\mathrm{OH})_{2}(\text { Ampibole })+14 \mathrm{CO}_{2}+22 \mathrm{H}_{2} \mathrm{O}= \\
2 \mathrm{Ca}^{2+}+5 \mathrm{Mg}^{2+}+14 \mathrm{HCO}_{3}^{-}+8 \mathrm{H}_{4} \mathrm{SiO}_{4}\end{array}$ & $\begin{array}{l}\mathrm{Ca}: \mathrm{HCO}_{3}=2: 7 \\
\mathrm{Mg}: \mathrm{HCO}_{3}=5: 7\end{array}$ \\
\hline b 8 & $\begin{array}{c}2 \mathrm{~K}\left(\mathrm{Mg}_{2} \mathrm{Fe}\right)\left(\mathrm{AlSi}_{3}\right) \mathrm{O}_{10}(\mathrm{OH})_{2}(\text { Biotite })+5 \mathrm{H}_{2} \mathrm{CO}_{3}+7 \mathrm{H}_{2} \mathrm{CO}_{3} \\
+7 \mathrm{H}_{2} \mathrm{O}=\mathrm{Al}_{2} \mathrm{Si}_{2} \mathrm{O}_{5}(\mathrm{OH})_{4}+2 \mathrm{~K}^{+}+4 \mathrm{Mg}^{2+}+2 \mathrm{Fe}(\mathrm{OH})_{3}+ \\
4 \mathrm{H}_{4} \mathrm{SiO}_{4}+5 \mathrm{HCO}_{3}^{-}\end{array}$ & $\begin{array}{l}\mathrm{Mg}: \mathrm{HCO}_{3}=4: 5 \\
\mathrm{~K}: \mathrm{HCO}_{3}=5: 2\end{array}$ \\
\hline b 9 & $\begin{array}{l}2 \mathrm{KAlSi}_{3} \mathrm{O}_{8}(\mathrm{~K} \text {-feldspar })+9 \mathrm{H}_{2} \mathrm{O}+2 \mathrm{H}_{2} \mathrm{CO}_{3}= \\
\mathrm{Al}_{2} \mathrm{Si}_{2} \mathrm{O}_{5}(\mathrm{OH})_{4}+2 \mathrm{~K}^{+}+2 \mathrm{HCO}_{3}^{-}+4 \mathrm{H}_{4} \mathrm{SiO}_{4}\end{array}$ & $\mathrm{~K}: \mathrm{HCO}_{3}=1: 1$ \\
\hline b 10 & $\mathrm{CaCO}_{3}+\mathrm{CO}_{2}+\mathrm{H}_{2} \mathrm{O}=\mathrm{Ca}^{2+}+2 \mathrm{HCO}_{3}^{-}$ & $\mathrm{Ca}: \mathrm{HCO}_{3}=1: 2$ \\
\hline b 11 & $\mathrm{CaMg}\left(\mathrm{CO}_{3}\right)_{2}+2 \mathrm{CO}_{2}+2 \mathrm{H}_{2} \mathrm{O}=\mathrm{Ca}^{2+}+\mathrm{Mg}^{2+}+4 \mathrm{HCO}_{3}^{-}$ & $\begin{array}{l}\mathrm{Ca}: \mathrm{HCO}_{3}=1: 2 \\
\mathrm{Mg}: \mathrm{HCO}_{3}=1: 2\end{array}$ \\
\hline
\end{tabular}

NOTE: ${ }^{\mathrm{a}}$ Taken from [14], ${ }^{\mathrm{b}}$ taken from [15], ${ }^{\mathrm{c}}$ taken from [16].

If $\mathrm{Ca}^{2+}$ and $\mathrm{SO}_{4}{ }^{2-}$ were derived from weathering of gypsum, the molar ratio of $\mathrm{Ca}^{2+} / \mathrm{SO}_{4}{ }^{2-}$ would be 1:1. Figure $6 \mathrm{c}$ showed the relation between $\mathrm{Ca}^{2+}$ and $\mathrm{SO}_{4}{ }^{2-}$. It was observed that most of the groundwater samples along the 1:1 trend line and $\mathrm{Ca}^{2+}$ increasing with $\mathrm{SO}_{4}{ }^{2-}$, suggesting that weathering of gypsum is a source for $\mathrm{Ca}^{2+}$ and $\mathrm{SO}_{4}{ }^{2-}$. Figure $6 \mathrm{c}$ also showed that samples of the confined groundwater and a part of unconfined groundwater lay over the 1:1 trend, implying that there may be an inverse cation exchange Equation (2) or weathering of calcite, dolomite and anorthite.

$$
\begin{aligned}
& 2 \mathrm{Na}^{+}+\mathrm{CaX}_{2} \rightarrow \mathrm{Ca}^{2+}+2 \mathrm{NaX} \\
& \mathrm{Ca}^{2+}+2 \mathrm{NaX} \rightarrow 2 \mathrm{Na}^{+}+\mathrm{CaX}_{2}
\end{aligned}
$$

The plot of $\left(\mathrm{Mg}^{2+}+\mathrm{Ca}^{2+}\right)$ versus $\left(\mathrm{HCO}_{3}{ }^{-}+\mathrm{SO}_{4}{ }^{2-}\right)$ can also determine the mineralization processes of groundwater. If the weathering of carbonate and sulfate minerals is the primary reaction in the groundwater, water samples will be along the 1:1 trend line. The samples will tend to lie in the right area when there is cation exchange Equation (1) occurring in the groundwater; water samples will locate at the left area of the diagram when an inverse cation exchange Equation (2) is occurring in the groundwater. As shown in Figure 6d, most of the groundwater samples lie along the 1:1 trend line, implying that the occurrence of dissolutions of carbonates and gypsum minerals. In addition, most of the confined groundwater samples and a part of the unconfined groundwater samples are observed to fall above the trend line of 1:1, indicating the effects of the inverse cation exchange process.

Reactions $(5-7,10,11)$ in Table 3 show the main processes that can release $\mathrm{Ca}^{2+}$ and $\mathrm{HCO}_{3}{ }^{-}$. Figure 6e is the bivariate plots of $\mathrm{Ca}^{2+}$ and $\mathrm{HCO}_{3}{ }^{-}$. According to those reactions, the ratios between $\mathrm{Ca}^{2+}$ and $\mathrm{HCO}_{3}{ }^{-}$from the weathering reactions are 1:1 (calcite), 1:2 (dolomite and anorthite), 1:1.7 (pyroxene), 2:7 (amphibole). Figure 6e suggests that part of the water samples are plotted above the 1:1 line, showing that the $\mathrm{HCO}_{3}{ }^{-}$is greater than $\mathrm{Ca}^{2+}$ and that the weathering of anorthite and dolomite occurs. And some water samples lie along the 1:1 trend line, which suggests that the main source of $\mathrm{Ca}^{2+}$ and $\mathrm{HCO}_{3}{ }^{-}$is weathering of calcite. Furthermore, most water samples are under the 1:1 line, indicating that there is an excess of $\mathrm{Ca}^{2+}$, which results from the dissolution of gypsum. On the whole, 
the important processes of the groundwater evolution are generally dissolution of gypsum, calcite, dolomite, amphiboles, pyroxene, and anorthites.

The $\mathrm{Mg}^{2+}$ vs. $\mathrm{HCO}_{3}{ }^{-}$relationship diagram has been used to reveal the sources of $\mathrm{Mg}^{2+}$ and $\mathrm{HCO}_{3}{ }^{-}$in groundwater. If the $\mathrm{Mg}^{2+}$ and $\mathrm{HCO}_{3}{ }^{-}$only derive from the dissolution of carbonate and the weathering of amphibole, biotite, and pyroxene, according to the chemical reactions (formulas 6-8,11 in Table 3), the $\mathrm{Mg}^{2+} / \mathrm{HCO}_{3}{ }^{-}$milliequivalent ratio will be dolomite (2:1 line), amphibole (7:5 line), biotite (5:8 line), and pyroxene (1.7:0.7 line), respectively. The relation of $\mathrm{Mg}^{2+}$ and $\mathrm{HCO}_{3}{ }^{-}$is shown in Figure 6f, and nearly all samples lie along the 2:1 line and 1.7:0.7 line, indicating a source of dolomite and pyroxene dissolution.

If $\mathrm{HCO}_{3}{ }^{-}$and $\mathrm{K}^{+}$mainly come from the weathering of $\mathrm{K}$-feldspar and biotite, according to the chemical reactions (formulas 8-9, in Table 3), the $\mathrm{HCO}_{3}{ }^{-} / \mathrm{K}^{+}$is 1:1 (K-feldspar) and 5:2 (biotite), respectively. As shown in Figure $6 \mathrm{~g}$, all water samples are above the line (1:1) and line (5:2). This suggests that the $\mathrm{HCO}_{3}{ }^{-}$is superfluous and that the weathering of $\mathrm{K}$-feldspar and biotite are rare in the groundwater. The $\mathrm{HCO}_{3}{ }^{-}$was mainly from the weathering of albite, plagioclase, and carbonate minerals.

The chlor-alkaline index (CAI) is an important way to study the occurrence of cation exchange [17, 18]. The CAI- 1 and CAI-II are estimated through the following equations (units of ions with meq/L):

$$
\begin{gathered}
\mathrm{CAI}-1=\frac{\mathrm{Cl}^{-}-\left(\mathrm{Na}^{+}+\mathrm{K}^{+}\right)}{\mathrm{Cl}^{-}} \\
\mathrm{CAI}-2=\frac{\mathrm{Cl}^{-}-\left(\mathrm{Na}^{+}+\mathrm{K}^{+}\right)}{\mathrm{CO}_{3}{ }^{2-}+\mathrm{SO}_{4}{ }^{2-}+\mathrm{HCO}_{3}{ }^{-}+\mathrm{NO}_{3}-}
\end{gathered}
$$

If the chlorine-alkalinity index is less than 0 , the normal cation exchange process is dominant for hydrochemistry. On the contrary, if the index is a positive value, a reverse cation exchange process takes place. Figure $6 \mathrm{~h}$ showed that all confined groundwater and most of the unconfined groundwater of the study area had negative chlorine-alkalinity index values, suggesting that $\mathrm{Na}^{+}$or $\mathrm{K}^{+}$in the aquifer have been substituted by $\mathrm{Ca}^{2+}$ or $\mathrm{Mg}^{2+}$ in the groundwater Equation (1). However, some unconfined groundwater samples are with positive index values, indicating a reverse cation exchange process Equation (2).

\subsection{Saturation Index and Mineral Dissolution}

Groundwater hydrochemistry was governed by many processes, such as groundwater flows, recharge and discharge processes, and water-rock reactions. Along the groundwater flow direction, hydrochemistry is always affected by minerals weathering in long residence time [19]. The saturation index (SI) of a mineral can be estimated by the following equation: $\mathrm{SI}=\log \left(\frac{\mathrm{K}_{\mathrm{IAP}}}{\mathrm{K}_{\mathrm{SP}}}\right)$ (where, $\mathrm{K}_{\mathrm{IAP}}$ is the ions activity product for a mineral equilibrium reaction, and $\mathrm{K}_{\mathrm{SP}}$ is the solubility product of the mineral). The PHREEQC software can be used to calculate the SI values of the minerals in groundwater [20]. The results of SI suggest the trend of water and mineral chemical equilibrium and water-rock interaction. If unsaturated $(\mathrm{SI}<0)$, the mineral will be continuously weathered by the groundwater; if supersaturated (SI $>0$ ), the mineral will precipitate; and if SI is close to 0, the mineral phase will remain in an equilibrium state. According to the hydrochemistry data, the saturation indices of particular minerals were calculated (Table 4).

The Saturation Index values of calcite and dolomite of a part of samples were greater than 0 , and those of the other samples were less than 0 (Table 4), indicating that the carbonate minerals keep gradually from unsaturation to supersaturation status. In contrast, the SI of halite and gypsum for all groundwater samples was less than 0 (Table 4), suggesting that the halite and gypsum will continuously dissolve in groundwater. 
Table 4. Saturation index of minerals (carbonate, gypsum, halite, silicate, and quartz) in groundwater.

\begin{tabular}{ccccc}
\hline $\begin{array}{c}\text { Saturation Index } \\
\text { of Minerals }\end{array}$ & Min & Max & Average & $\begin{array}{c}\text { Standard } \\
\text { Deviation }\end{array}$ \\
\hline $\mathrm{SI}_{\text {calcite }}$ & -0.73 & 1.34 & 0.18 & 0.49 \\
$\mathrm{SI}_{\text {dolomite }}$ & -1.73 & 3.12 & 0.21 & 0.97 \\
$\mathrm{SI}_{\text {gypsum }}$ & -2.67 & 0.12 & -1.40 & 0.48 \\
$\mathrm{SI}_{\text {halite }}$ & -8.35 & -3.23 & -6.44 & 0.82 \\
$\mathrm{SI}_{\text {quartz }}$ & -1.76 & 0.62 & -0.76 & 0.86 \\
$\mathrm{SI}_{\text {illite }}$ & -11.41 & 1.51 & -5.81 & 5.13 \\
$\mathrm{SI}_{\mathrm{K}-f e l d s p a r}$ & -6.89 & 0.24 & -3.81 & 2.59 \\
$\mathrm{SI}_{\text {albite }}$ & -7.48 & -0.89 & -4.72 & 2.57 \\
$\mathrm{SI}_{\text {gibbsite }}$ & -3.32 & 0.58 & -1.64 & 1.74 \\
$\mathrm{SI}_{\text {kaolinite }}$ & -9.19 & 2.90 & -3.98 & 5.19 \\
$\mathrm{SI}_{\text {montmorillonite }}$ & -14.21 & 1.80 & -7.31 & 6.62 \\
\hline
\end{tabular}

The Saturation Index values of calcite and dolomite ranged from -0.73 to 1.34 and -1.73 to 3.12 , with mean values of 0.18 and 0.21 , respectively. Figure $7 \mathrm{~b}$ showed that there was a bad correlation between SI and TDS. In addition, the concentrations of $\mathrm{Ca}^{2+}, \mathrm{HCO}_{3}{ }^{-}, \mathrm{Mg}^{2+}, \mathrm{HCO}_{3}{ }^{-}$were not correlating with SI calcite (Figure 7e) and $\mathrm{SI}_{\text {dolomite }}$ (Figure 7f), which indicate that the weathering of calcite and dolomite did not continue, and only a part of the minerals will be continuously dissolving along the groundwater flow direction. On the contrary, $\mathrm{SI}_{\text {halite }}$ and $\mathrm{SI}_{\text {gypsum }}$ were less than 0 and positively correlated with TDS (Figure 7a,b). Moreover, $\mathrm{Na}^{+}$and $\mathrm{Cl}^{-}, \mathrm{Ca}^{2+}$, and $\mathrm{SO}_{4}{ }^{2-}$ show high correlation coefficients ( $\mathrm{R}^{2}$ equal to 0.974 and 0.915 , respectively, Table 2 ). This suggests that the halite and gypsum will be continuing dissolved in groundwater along the flow direction. At the same time, the addition of $\mathrm{Ca}^{2+}$ from the weathering of gypsum could lead to supersaturation of calcite and dolomite, thus inhibiting the weathering of calcite and dolomite. Figure $7 \mathrm{c}, \mathrm{d}$ represent the scatter plots of $\mathrm{Na}^{+}, \mathrm{Cl}^{-}$ versus $\mathrm{SI}_{\text {halite }}$ and $\mathrm{Ca}^{2+}, \mathrm{SO}_{4}{ }^{2-}$ versus $\mathrm{SI}_{\text {gypsum, }}$ and the correlation coefficients $\mathrm{R}^{2}$ are $0.975,0.99,0.948$, and 0.941 , respectively. The dissolution of halite and gypsum can produce exponential increases of $\mathrm{Na}^{+}, \mathrm{Cl}^{-}$and $\mathrm{Ca}^{2+}, \mathrm{SO}_{4}{ }^{2-}$, suggesting that halite and gypsum are the main minerals along the flow direction.

Because the stratum of the study area is mainly the Quaternary strata containing a large amount of clay minerals, there may be dissolution of aluminosilicate minerals, especially albite, anorthite, and plagioclase. This explanation is also supported by previous studies (Table 5) [21,22].

Table 5. Mineral content percentage in the study area [21,22]. (SD: Standard Deviation, CV: Coefficient of Variation).

\begin{tabular}{cccccccccc}
\hline $\begin{array}{c}\text { Mineral } \\
\text { Content }\end{array}$ & Quartz & Plagioclase & Microcline & Illite & Chlorite & Calcite & Dolomite Gypsum & Halite \\
\hline Mean (\%) & 44.22 & 11.70 & 6.08 & 7.03 & 6.07 & 18.02 & 2.73 & 2.90 & 1.09 \\
Max (\%) & 77.41 & 32.53 & 18.38 & 23.22 & 23.62 & 52.31 & 9.49 & 83.44 & 4.62 \\
Min (\%) & 0.50 & 1.92 & 0.00 & 0.98 & 0.02 & 3.08 & 0.00 & 0.00 & 0.00 \\
SD & 13.10 & 5.07 & 3.66 & 5.02 & 4.28 & 7.03 & 1.62 & 12.80 & 1.28 \\
CV (\%) & 30.70 & 43.38 & 60.14 & 71.45 & 70.53 & 39.01 & 59.13 & 441.31 & 118.21 \\
\hline
\end{tabular}



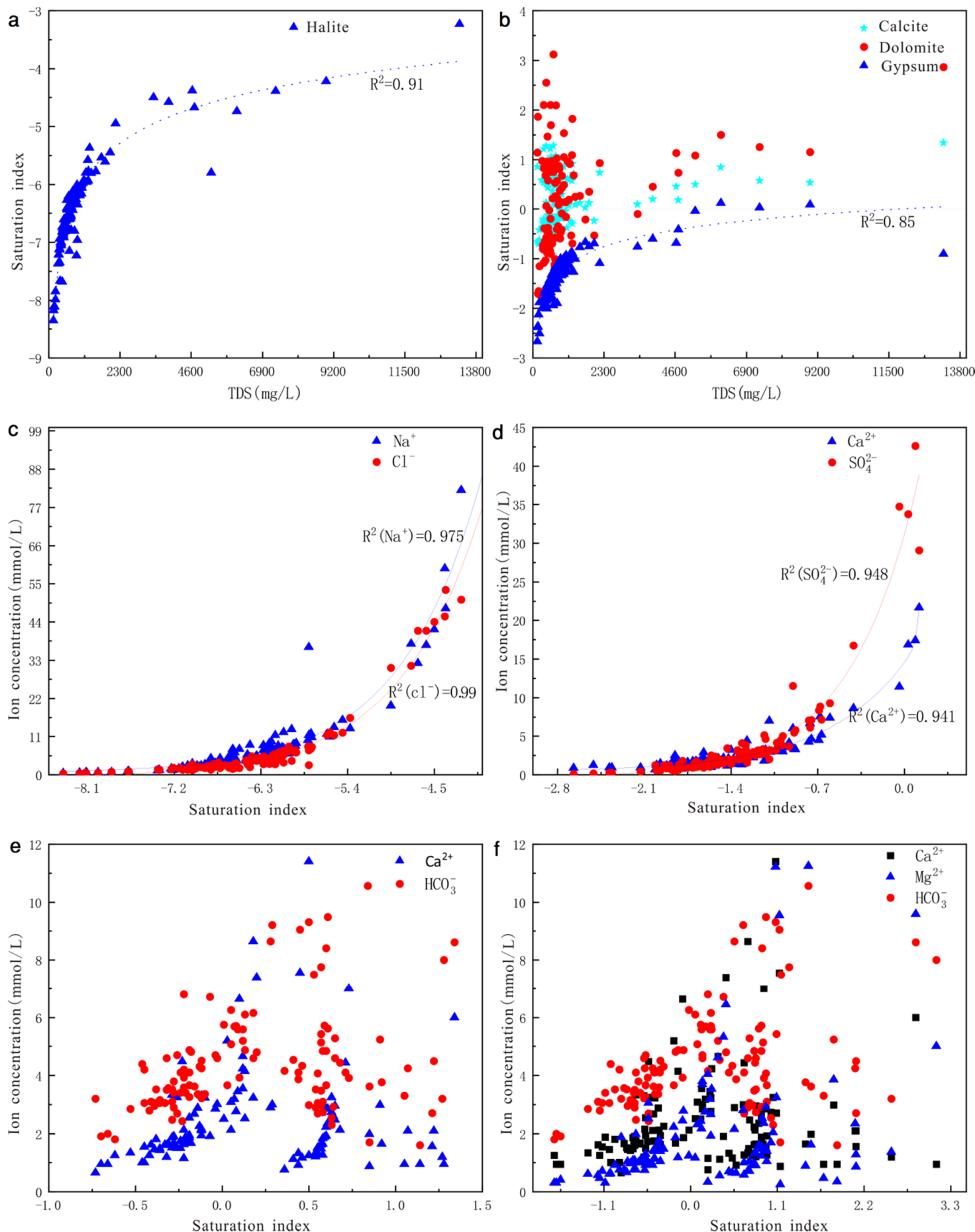

Figure 7. Saturation indices plots with selected minerals versus TDS or ion concentration. (a) $\mathrm{SI}_{\text {halite }}$ vs. TDS, (b) SI gypsum, $\mathrm{SI}_{\text {calcite, }} \mathrm{SI}_{\text {dolomite }}$ vs. TDS, (c) $\mathrm{Na}^{+}, \mathrm{Cl}^{-}$vs. $\mathrm{SI}_{\text {halite, }}$ (d) $\mathrm{Ca}^{2+}, \mathrm{SO}_{4}{ }^{2-}$ vs. $\mathrm{SI}_{\text {gypsum, }}$ (e) $\mathrm{Ca}^{2+}, \mathrm{HCO}_{3}{ }^{-}$vs. $\mathrm{SI}_{\text {calcite, }}(\mathbf{f}) \mathrm{Ca}^{2+}, \mathrm{Mg}^{2+}, \mathrm{HCO}_{3}{ }^{-}$vs. $\mathrm{SI}_{\text {dolomite. }}$

In addition, mineral stability diagrams were another important way to assess the degree of the fluid-rock equilibrium [23]. Figure 8 shows the Ca-, Na-, K-, and Mg-aluminosilicates stability diagrams of 43 water samples in this area. The software PHREEQC was applied to calculate the activities of ions, such as $\mathrm{Ca}^{2+}, \mathrm{Mg}^{2+}, \mathrm{Na}^{+}, \mathrm{K}^{+}$, and $\mathrm{H}_{4} \mathrm{SiO}_{4}$. The stability field diagrams of $\mathrm{Ca}-, \mathrm{Mg}-$, and Na-aluminosilicates (Figure $8 \mathrm{a}-\mathrm{c}$ ) showed that most of the unconfined groundwater samples lay in the stability region of kaolinite, while a few unconfined and all confined groundwater samples lay 
in the stability region of montmorillonite. Meanwhile, a number of water samples were located in the boundary between the stability fields of kaolinite and montmorillonite. And only one unconfined groundwater sample lay in the stability field of Gibbsite. Those results of Figure 8a-c showed that kaolinite and montmorillonite were in equilibrium. On the $\mathrm{K}^{+}-\mathrm{H}^{+}-\mathrm{SiO}_{2}$ system plot (Figure $8 \mathrm{~d}$ ), all water samples fall in the stability field of illite, suggesting that illite is stable. To sum up, kaolinite, montmorillonite, and illite will be in equilibrium with the groundwater in this study area. Figure 8a-d showed that no water samples lay in the Amesite, Anorthite, Albite, or K-feldspar stability field. Some previous researches indicated that water samples keeping in equilibrium with kaolinite reflected good drainage conditions [24]. Table 6 shows the ${ }^{14} \mathrm{C}$ age of the local groundwater within the age of 5000-7000 years, indicating that the groundwater has relatively fast-updating capacity and that the groundwater runoff condition is good.
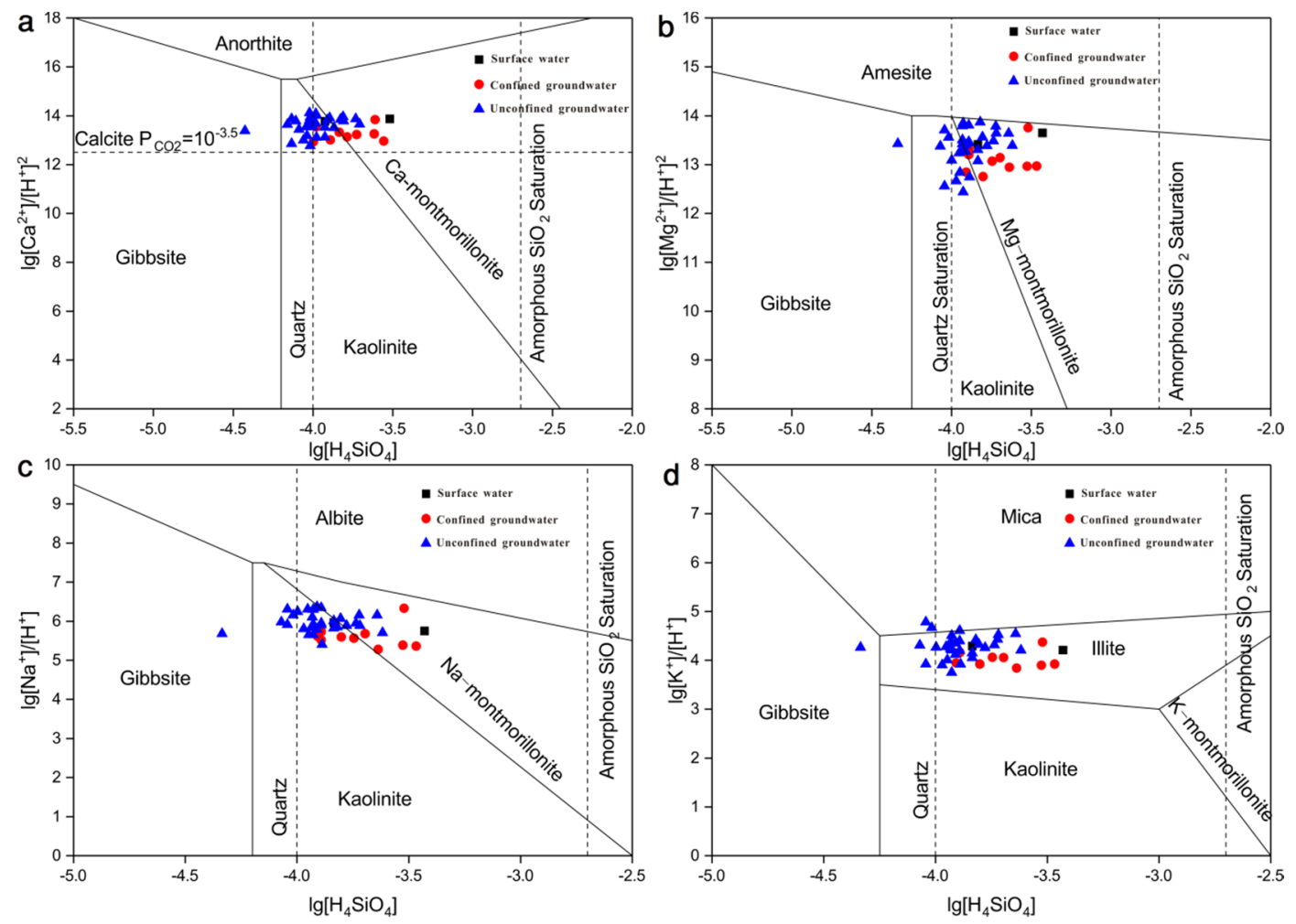

Figure 8. Stability diagram for silicate systems (a) $\mathrm{Ca}^{2+}-\mathrm{H}^{+}-\mathrm{SiO}_{2}$, (b) $\mathrm{Mg}^{2+}-\mathrm{H}^{+}-\mathrm{SiO}_{2}$, (c) $\mathrm{Na}^{+}-\mathrm{H}^{+}-\mathrm{SiO}_{2}$, (d) $\mathrm{K}^{+}-\mathrm{H}^{+}-\mathrm{SiO}_{2}$.

Table 6. Groundwater ages in the study area.

\begin{tabular}{cc}
\hline Sampling Point Location & Groundwater Age (ka) \\
\hline Delingha City Water Source Well (DCWSW) & $5.165 \pm 0.04$ \\
BK3 & $5.17 \pm 0.17$ \\
QZ2 & $5.38 \pm 0.2$ \\
QZ4 & $7.05 \pm 0.17$ \\
Confined Groundwater of Gahai Lake & $5.385 \pm 0.06$ \\
\hline
\end{tabular}

The four main feldspars stability diagrams and $\mathrm{HCO}_{3}{ }^{-}$versus $\mathrm{Na}^{+}, \mathrm{Ca}^{2+}, \mathrm{Mg}^{2+}, \mathrm{K}^{+}$bivariate plots indicated that there was weathering of aluminosilicate minerals, such as albite, plagioclase, anorthite, pyroxene, and amphibole in the study area (reactions of 3-7 in Table 3). 


\subsection{Implication for the Groundwater Resource Management}

According to the result of TDS distribution along the groundwater flow direction (Figure 4), the groundwater quality in different areas and different aquifers can be concluded. As shown in Table 1 , it can be learned that the confined groundwater is fresh water, even in the downstream area. However, as shown in Figure 4, along the flow direction, the unconfined groundwater was divided into three zones: fresh groundwater zone (TDS $<1 \mathrm{~g} / \mathrm{L})$, slightly salty groundwater zone $(1 \mathrm{~g} / \mathrm{L}<\mathrm{TDS}<3 \mathrm{~g} / \mathrm{L})$ and salty groundwater zone (TDS $>3 \mathrm{~g} / \mathrm{L}$ ). This can provide information for the local groundwater development. All the confined groundwater in this study area can be pumped for drinking water; however, only the fresh unconfined groundwater zone can be selected as the water resource field.

The result of the groundwater hydrochemical types (Figures 2 and 4) indicates that the $\mathrm{HCO}_{3}{ }^{-}$type groundwater, which means high quality water, is mainly located in the northern area. The $\mathrm{HCO}_{3}{ }^{-}$type groundwater can be supplied for a domestic water source. The $\mathrm{SO}_{4}{ }^{2-}$ type groundwater can be supplied for agricultural and industrial consumption. Thus, this study can support the reasonable utilization and management of differentiated water. In addition, the result of the hydrochemistry difference between unconfined and confined groundwater implies the weak connection between those two aquifers in the lacustrine plain area. This can provide information for the elaborate hydrogeological modeling study of the groundwater resource assessment. Furthermore, the results of the hydrochemistry evolution indicate that the hydrochemical composition of groundwater is derived from dissolutions of evaporite minerals (halite and gypsum) and carbonate minerals (such as calcite and dolomite), aluminosilicate weathering and cation exchange. This result of mineral sources of groundwater can provide basic data for the refined groundwater pollution research.

\section{Conclusions}

A comprehensive analysis of hydrochemical data of 123 water samples in the Delingla area were conducted to provide a basis for understanding the major ions origins, distribution, and associated hydrogeochemical evolutions along the flow path and supporting the the local groundwater resource management.

The results showed that groundwater hydrochemistry has obvious zoning distribution in this area. TDS of groundwater is gradually increasing from the mountain area to the lacustrine plain. Furthermore, groundwater is characterized by $\mathrm{HCO}_{3}-\mathrm{Ca} \cdot \mathrm{Mg}$ and $\mathrm{HCO}_{3} \cdot \mathrm{SO}_{4}-\mathrm{Ca} \cdot \mathrm{Mg}$ types in the mountain area (recharge area), $\mathrm{SO}_{4} \cdot \mathrm{HCO}_{3}-\mathrm{Ca} \cdot \mathrm{Mg}$ and $\mathrm{SO}_{4} \cdot \mathrm{Cl}-\mathrm{Ca} \cdot \mathrm{Mg}$ types in the alluvial-lacustrine plain (runoff area), and $\mathrm{Cl} \cdot \mathrm{SO}_{4}-\mathrm{Na}$ and $\mathrm{Cl}-\mathrm{Na}$ types in the lacustrine plain (discharge area). The ions ratio relations, mineral saturation index, and mineral stability diagrams suggest that the dominating hydrochemical processes were dissolutions of evaporite minerals (halite and gypsum) and carbonate minerals (such as calcite and dolomite), aluminosilicates weathering, and cation exchange. The results of this study can provide references for further understanding of the groundwater geochemical evolution processes in this area and other similar areas. In addition, the hydrochemistry characteristics and groundwater evolution can guide the selection of water resource fields and provide information for the elaborate assessment and protection of groundwater resources.

Author Contributions: P.Z. and G.W. conceived and review \& editing the manuscript; B.Z. wrote the original draft of the manuscript; D.Z. analyzed the chemistry data; F.L. plotted the figures; S.Q. analyzed the geochemistry process in the groundwater. All authors have read and agreed to the published version of the manuscript.

Funding: This work was supported by the National Natural Science Foundation of China (Grant Nos. 41672243, U1602233, 41272269) and the China Geological Survey Program (Grant Nos. 1212011121277, 12120115046301, DD20160291, DD20189270).

Conflicts of Interest: The authors declare no conflict of interest. 


\section{References}

1. Elgallal, M.; Fletcher, L.; Evans, B. Assessment of potential risks associated with chemicals in waste water used for irrigation in arid and semiarid zones: A review. Agric. Water Manag. 2016, 177, 419-431. [CrossRef]

2. Lu, S.; Zhang, X.; Liang, P. Influence of drip irrigation by reclaimed water on the dynamic change of the nitrogen element in soil and tomato yield and quality. J. Clean Prod. 2016, 139, 561-566. [CrossRef]

3. Wang, L.; Dong, Y.; Xie, Y.; Song, F.; Wei, Y.; Zhang, J. Distinct groundwater recharge sources and geochemical evolution of two adjacent sub-basins in the lower shule river basin, northwest China. Hydrogeol. J. 2016, 24, 1967-1979. [CrossRef]

4. Xiao, Y.; Shao, J.L.; Cui, Y.L.; Zhang, G.; Zhang, Q.L. Groundwater circulation and hydrogeochemical evolution in Nomhon of Qaidam Basin, northwest China. J. Earth Syst. Sci. 2017, 126, 26. [CrossRef]

5. Jiao, J.J.; Zhang, X.; Liu, Y.; Kuang, X. Increased water storage in the Qaidam Basin, the North Tibet Plateau from GRACE gravity data. PLoS ONE 2015, 1010, e0141442. [CrossRef] [PubMed]

6. Li, P.; Qian, H.; Howard, K.W.F.; Wu, J. Building a new and sustainable "Silk Road economic belt". Environ. Earth Sci. 2015, 74, 7267-7270. [CrossRef]

7. Moral, F.; Cruz-Sanjulian, J.J.; Olias, M. Geochemical evolution of groundwater in the carbonate aquifers of Sierra de Segura (BeticCordillera, southern Spain). J. Hydrol. 2008, 360, 281-296. [CrossRef]

8. Gastmans, D.; Chang, H.K.; Hutcheon, I. Groundwater geochemical evolution in the northern portion of the Guarani Aquifer System (Brazil) and its relationship to diagenetic features. Appl. Geochem. 2010, 25, 16-33. [CrossRef]

9. Zhu, P.; Su, X.; Zhang, S.; Huang, Y.; Yang, F. Study on the Interaction Relationship between Surface Water and Groundwater in Nalingguole River Alluvial Proluvial Fan. Yellow River 2014, 36, 60-64. (In Chinese)

10. Wagh, V.M.; Panaskar, D.B.; Varade, A.M.; Mukate, S.V.; Gaikwad, S.K.; Pawar, R.S.; Muley, A.A.; Aamalawar, M.L. Major ion chemistry and quality assessment of the groundwater resources of nandedtehsil, a part of Southeast Deccan Volcanic Province, Maharashtra, India. Environ. Earth Sci. 2016, 75, 1418. [CrossRef]

11. Piper, A.M. A graphic procedure in the geochemical interpretation of water analysis. Eos. Trans. Am. Geophys. Union 1944, 25, 914-928. [CrossRef]

12. Subrahmanyam, K.; Yadaiah, P. Assessment of the impact of industrial effluents on water quality in Patancheru and environs, Medak district, Andhra Pradesh, India. Hydrogeol. J. 2001, 9, 297-312. [CrossRef]

13. Gibbs, R.J. Mechanisms controlling world water chemistry. Science 1970, 170, 1088-1090. [CrossRef] [PubMed]

14. Adams, S.; Titus, R.; Pietersen, K.; Tredoux, G.; Harris, C. Hydrochemical characteristics of aquifers near Sutherland in the western Karoo, South Africa. J. Hydrol. 2001, 241, 91-103. [CrossRef]

15. Walraevens, K.; Bakundukize, C.; Mtoni, Y.E.; Van Camp, M. Understanding the hydrogeochemical evolution of groundwater in Precambrian basement aquifers: A case study of Bugesera region in Burundi. J. Geochem. Explor. 2018, 188, 24-42. [CrossRef]

16. Kim, K. Plagioclase weathering in the groundwater system of a sandy, silicate aquifer. Hydrol. Process. 2002, 16, 1793-1806. [CrossRef]

17. Li, P.; Wu, H.; Qian, H. Assessment of groundwater quality for irrigation purposes and identification of hydrogeochemical evolution mechanisms in Pengyang County, China. Environ. Earth Sci. 2013, 69, 2211-2225. [CrossRef]

18. Huang, X.J.; Wang, G.C.; Liang, X.Y.; Cui, L.F.; Ma, L.; Xu, Q. Hydrochemical and stable isotope $\left(\delta \mathrm{D}\right.$ and $\left.\delta^{18} \mathrm{O}\right)$ characteristics of groundwater and hydrogeochemical processes in the Ningtiaota Coalfield, Northwest China. Mine Water Environ. 2018, 37, 119-136. [CrossRef]

19. Wen, X.H.; Wu, Y.Q.; Wu, J. Hydrochemical characteristics of groundwater in the Zhangye Basin, Northwestern China. Environ. Geol. 2008, 55, 1713-1724. [CrossRef]

20. Parkhurst, D.L.; Appelo, C.A.J. User's Guide to PHREEQC (Version 2) a Computer Program for Speciation, Batch-Reaction, One-Dimensional Transport, and Inverse Geochemical Calculations: U.S Geological Survey Water-Resources Investigations Report 99-4259. 1999. Available online: https:/pubs.er.usgs.gov/publication/ wri994259 (accessed on 21 October 2018).

21. Zhang, X.Y.; Ma, H.Z.; Han, F.Q.; Chen, Z.H. Mineral Assemblages and Palaeo environmental Changes of Core DG03 of Gahai Lake in Delingha Basin. Acta Sedmentol. Sin. 2007, 25, 767. (In Chinese) 
22. Zhang, X.Y.; Qu, J.W.; Zhang, W. Age model and palaeo climatic changes of DG03 core of Gahai Lake in Delingha Basin. J. Ludong Univ. 2009, 25, 68-72. (In Chinese)

23. Xing, L.; Guo, H.; Zhan, Y. Groundwater hydrochemical characteristics and processes along flow paths in the North China Plain. J. Asian Earth Sci. 2013, 70-71, 250-264. [CrossRef]

24. Wang, Y.; Shvartsev, S.L.; Su, C. Genesis of arsenic/fluoride-enriched soda water: A case study at Datong, northern China. Appl. Geochem. 2009, 24, 641-649. [CrossRef]

(C) 2020 by the authors. Licensee MDPI, Basel, Switzerland. This article is an open access article distributed under the terms and conditions of the Creative Commons Attribution (CC BY) license (http://creativecommons.org/licenses/by/4.0/). 